\title{
THE EFFECT OF TAX INCENTIVES AND TAX KNOWLEDGE ON CORPORATE TAXPAYER COMPLIANCE DURING THE COVID-19 PANDEMIC AND INTENTION AS MODERATING
}

\author{
Gede Udik Apriadi ${ }^{1}$ \\ Ni Made Dwi Ratnadi ${ }^{2}$ \\ Maria Mediatrix Ratna Sari ${ }^{3}$ \\ I Gusti Ayu Made Asri Dwija Putri ${ }^{4}$
}

Faculty of Economics and Business, Udayana University, Bali, Indonesia

Email: gedeudikapriadi14@gmail.com

\begin{abstract}
This study aims to obtain empirical evidence of the effect of tax incentives and tax knowledge on taxpayer compliance, taxpayer intention to moderate the effect of tax incentives on taxpayer compliance and taxpayer intention to moderate the effect of tax knowledge on taxpayer compliance. The sample used in the study was 100 corporate taxpayers. Determination of the sample is done by non-probability method with purposive sampling technique. The data used is primary data collected through survey techniques with questionnaires. The data analysis technique used is moderation regression analysis (MRA). The results obtained are tax incentives have an effect on taxpayer compliance, tax knowledge has an effect on taxpayer compliance, taxpayer intentions strengthen the effect of tax incentives on taxpayer compliance and taxpayer intentions strengthen the effect of tax knowledge on taxpayer compliance. Regarding the theoretical implications, tax incentives and tax knowledge are external and internal factors that affect corporate taxpayer compliance, especially if the corporate taxpayer has the intention to comply. So the results of the study confirm the theory of TPB and attribution.
\end{abstract}

Keywords: incentive, intention, knowledge and compliance

DOI: $10.7176 /$ RJFA/13-1-04

Publication date: January $31^{\text {st }} 2022$

\section{INTRODUCTION}

The high target of state tax revenue is not supported by an increase in taxpayer compliance. Compliance from taxpayers is one of the problems faced by the state in collecting tax revenues. The emergence of the Covid19 pandemic problem since early 2020 has also affected taxpayer compliance in Indonesia so that it has an impact on state revenues. This can be seen from Indonesia's tax ratio which continues to decline from year to year before and after the pandemic. The tax ratio in 2013 which was able to reach $11.86 \%$ continued to decline and reached its lowest point before the Covid-9 pandemic in 2019 yesterday at 9.76\% (DDTC News, 2020) and after Covid in 2020 it decreased again to $8 \%$. The government has set a tax ratio target for 2021 at $8.2 \%$ of Gross Domestic Product (GDP). It must be admitted that in Indonesia, the tax ratio is still low (Sri Mulyani, 2020). Indonesia's tax ratio should reach 13 to 14 percent when compared to ASEAN countries. Minister of Finance (Menkeu) Sri Mulyani Indrawati encourages the Directorate General of Taxes (DGT) to carry out reforms in various fields in an effort to increase state revenues and the tax ratio (PajakOnline.com, 2021)). The Directorate General of Taxes (DGT) has taken various ways to increase the tax ratio both before and after the pandemic. Programs implemented before the pandemic included the sunset policy in 2008 and the tax amnesty in 2016. However, these policies did not have a significant impact on Indonesia's tax ratio.

The Covid-19 pandemic has been declared by the government as a non-natural disaster. Darrusalam (2020), the Covid-19 pandemic is a world health crisis that also has an impact on recessions in various countries. Since March, the IMF has even predicted the arrival of a global economic recession that could be worse than the 2008 global financial crisis (IMF, 2020). By the three international institutions, Indonesia's economic growth is predicted to remain much better than global and ASEAN trends. All three predict that the Indonesian economy in 2020 will grow between $-3.3 \%$ (OECD), $0 \%$ (World Bank), and IMF (-0.3\%). The Indonesian government, through the Minister of Finance, has its own calculation which ranges from -1.7\% to $-0.6 \%$ (23 September 2020). The threat of a recession is considered by governments in many countries to issue various tax relaxation policies. goal, prevent unemployment, stabilize investment, maintain cash flow in the business sector, encourage consumption, and so on (OECD, 2020). Indonesia is no exception. 
Suahasil (deputy minister of finance, 2020) stated that the fall in tax revenue was due to a significant decrease in revenue at various tax revenue posts. One of the revenue blows is experienced by corporate taxpayers' tax receipts. Conditions of economic pressure due to restrictions on community activitiesnot only affects tax revenue but also the response of taxpayers to compliance with paying and reporting their tax obligations. Widiiswa, et al (2021) stated that when in a situation of economic crisis, the incentive of taxpayers to comply with tax obligations decreased. This is supported by research, Riyanto and Mudara, (2021) also found that the Covid-19 pandemic had a negative impact in the form of a decrease in tax revenue at the Large Two Taxpayer KPP.

The low submission of corporate tax returns and a decrease in tax revenues also occurred at the Bali Regional Office of the DGT. Goro Ekanto revealed that in terms of compliance with the submission of the Annual SPT until the 3rd quarter of 2020 , it had reached 280,548 SPT or $64.9 \%$ of the target of 431,888 taxpayers, with details of realization for Corporate taxpayers as many as 19,464 SPT out of 30,440 Corporate Taxpayers who have the obligation to report SPT. Annually, non-employee individual taxpayers (OP) are 36,033 SPT, WP OP Employees are 225,051 SPT (Balitribune, 2020). Until the last quarter of 2020, the Regional Office of the Directorate General of Taxes Bali (Kanwil DJP Bali) recorded a realization of tax revenues of Rp. 6.212 trillion, or $68.83 \%$ of the revenue target of Rp. 9.024 trillion. Realization of revenue from the Regional Office of DJP Bali in the last quarter experienced a growth of $-27.72 \%$ compared to the realization of revenue in the previous year. This is expected to continue until tax revenue is received in semester II/2021 because it will face challenges due to restrictions on community activities amid the increase in Covid-19 cases.

According to Sri Mulyani (2021), tax officials should not lose their enthusiasm for collecting taxes in the midst of a pandemic like today because there are still several business sectors that are not affected by the pandemic which must continue to be monitored and tax collections that should be in accordance with the law to prevent naughty taxpayers. taking advantage of the pandemic. Various studies have been carried out and the conclusion is that compliance issues can be viewed from the perspective of public finances, law enforcement, organizational structure, workforce, ethics or a combination of all these aspects. According to Maharani (2015) in order to achieve the tax target, taxpayer awareness and compliance is required to fulfill tax obligations in accordance with applicable regulations.

From various definitions of tax compliance, Adelina (2021) concludes that tax compliance contains several elements, such as willingness (willingness), reporting all income (reporting all income), declare the correct income (stating actual income), and timeliness / on time elements. (on time) and right amount of tax (right amount of tax payable).

ToTaxpayer compliance during the pandemic is thought to be influenced by tax incentives. Research on tax incentives conducted byAlfina (2021), Latief et al (2020), Indaryani (2020), Loupatty (2021), Salman Alief et al (2020), Nurul Aisyah Rachmawati and Rizka Ramayanti (2016) show that income tax incentives have a positive effect on increasing taxpayer compliance. While the research conducted byKhairiyah and Akhmadi (2019), Selvi and Ramdhan (2020), Syanti Dewi, Widyasari and Nataherwin (2020, Fochmann \& Kroll (2016); Kastlunger et al. (2011) explain that tax incentives have no effect on taxpayer compliance

Taxpayer compliance in addition to being influenced by tax incentives which as an external factor from the taxpayer, there are internal taxpayer factors that affect taxpayer compliance, namely tax knowledge. According to Yulianti (2019), Mandowally and Nugrahanto (2020), Adelina and Nugrahanto (2021), Faizal et al (2021), Dicriyani (2016), Kadek Juniati Putri and Putu Ery Setiawan (2017), Murti et al. (2014), Syahril (2013), and Masruroh and Zulaikha (2013) state that tax knowledge has a significant effect on taxpayer compliance. The results of this study are not in line with the researchAjeng Resti Fauzi and Kholida Atiyatul Maula (2020),Darmayasa and Mandia (2019), Nora Hilmia Primasari (2016), Sigit Herdianto (2021), Fita Fitrianingsih, Sudarno, and Taufik Kurrohman (2018), Hardiningsih and Yulianawati (2011), Pranadata (2014), Ratnadi and Putra (2019) and Hardiningsih and Yulianawati (2011) stated that Knowledge or understanding of taxpayers has no effect on taxpayer compliance. This means that the education received by the taxpayer or the knowledge of the taxpayer does not guarantee the taxpayer to comply with the tax system.

The results of previous studies indicate that there are inconsistencies in the results of the research obtained. So this study wants to review the effect of tax incentives and tax knowledge on taxpayer compliance with the taxpayer's intention as moderating. The difference with previous research is that this study adds the taxpayer's intention variable as a moderating variable of the effect of tax incentives and tax knowledge, the respondents used are corporate taxpayers who are entitled to take advantage of tax incentives and the data collection media used is a google form questionnaire distributed via email and whatsapps to the target respondent obtained from a tax consultant office that has a client at KPP Pratama North Badung.

According to Vanistendael (2020), with a pandemic that providespressure for all aspects of the economy, it is necessary to deepen the extent to which each party has contributed equitably. Furthermore, Vanistendael (2020) also emphasized the momentum to review socio-economic inequality in society through the tax system. In addition, the existence of a pandemic has prompted fundamental questions about the importance 
of mutual cooperation (contribution) by citizens.According to Field and Frey (2011) tax compliance is the implication of the existence of a psychological contractual relationship between the obligations and rights of each party that engages in the relationship, namely taxpayers and the state. Taxpayers usually report the amount of income earned in accordance with the fiscal provisions set by the government, provided that they receive facilities that are proportional to the amount of tax that has been issued in a reasonable legitimacy process. The existence of a pandemic that makes every country strive to provide the best public services and goods for its citizens should also be a signal of efforts to restore the fiscal contract between the state and society. The reciprocal relationship that has now been shown from the sacrifice of the state should need to be reciprocated by citizens through paying tax compliance.

Intention is the basis that will direct a person to comply with tax provisions. Taxpayer intentions can affect the relationship between tax incentives and tax knowledge on compliance. If taxpayers have high intentions with their obligations to pay taxes coupled with the Covid-19 pandemic tax incentives provided by the government and good tax knowledge, it can increase taxpayer compliance.

The psychological aspect of taxpayers can be studied with the Theory of Planned Behavior (TPB) which is the latest version of The Theory of Reasoned Action (TRA). The Theory of Reasoned Action and Theory of Planned Behavior are theories that can explain taxpayer compliance with tax provisions. The theory of reasoned action proposed by Ajzen and Fishbein (1980), and updated with the theory of planned behavior by Ajzen (1991), has been used to examine the intention and compliance of taxpayers. The theory of planned behavior (Ajzen, 1991), assumes that behavior is determined by the taxpayer's intention to comply or not comply with tax provisions. Intention to behave (behavior intention) is influenced by three components, namely: behavioral beliefs, normative beliefs, and control beliefs. Behavioral belief, namely belief in the outcome of a behavior (outcome belief) and evaluation of the outcome of that behavior. Beliefs and evaluation of these results will form the attitude variable towards the behavior. Normative belief, namely the individual's belief in the normative expectations of others who become his reference, such as family, friends, and tax consultants, and the motivation to achieve these expectations. This normative expectation forms the subjective norm variable for a behavior. The third is control belief, namely the individual's belief about the existence of things that support or hinder his behavior and his perception of how strongly these things affect his behavior.

Asmarany (2020) states that there are three factors that determine a person's intention to behave in a certain way, namely: behavioral beliefs, normative beliefs, and control beliefs. According to Hidayat and Adhi (2010), tax non-compliance behavior is based on the intention to not comply with taxes. Ajzen (1991), Bobek and Hatfield (2003) and Hanno and Violette (1996) state that attitudes toward tax non-compliance have a significant effect on tax non-compliance intentions. In Mustikasari's research (2007) concluded that tax professionals who have a positive attitude towards non-compliance have high tax non-compliance intentions. Tax non-compliance behavior according to Hidayat and Nugroho (2010) is based on the intention to not comply with taxes.

\section{LITERATURE REVIEW AND HYPOTHESES DEVELOPMENT}

Tax incentives can be defined in terms of their effect on deductions effective tax burden for a particular project. Tax incentives are assistance from the government to certain taxpayers who can be individuals or companies to increase income or reduce business costs and risks. Incentivef taxation is an incentive provided by the government for Indonesian taxpayers during this Covid-19 pandemic.

The phenomenon that has been described is the reason this research was conducted. This is due to the current situation so that the government is being tested to take appropriate fiscal steps in overcoming the deplorable economic conditions, this will also lead to public confidence in the government's efforts to overcome the fiscal gap. If the government shows a step forward in this policy, then the community will feel the benefits, so that taxpayer compliance will be more realized. Because taxpayer compliance is the spirit of state revenue in the tax sector. Thus, the government always strives to assist various business sectors in the form of reducing tax rates such as: corporate income tax (Corporate Income Tax), as well as incentives for Income Tax Article 21 borne by the government, reduction of Income Tax Article 25,

If it is related to research, the Theory of Planned of Behavior is relevant to interpret the behavior of taxpayers to be able to fulfill all their tax obligations. According to (Ajzen, 1985), the attitude towards the described behavior can link tax incentives with taxpayer compliance. This theory explains that this relationship can be built with the presence of internal and external factors. The tax incentives provided by the government include external factors from taxpayers. The tax incentive factor used by taxpayers can ease the burden of paying taxes because the taxes that should be paid by both companies and individuals will be borne by the government. So that taxpayers are expected to continue to carry out their tax obligations in accordance with tax provisions, namely depositing accrued taxes after receiving incentive benefits and submitting notification letters on time.

Research conducted by Rachmawati \& Ramayanti (2016); Latif \& Zakaria (2020); Khairiyah \& Akhmadi (2019); Kihanga (2020); Indrayani \& Budiman (2020); Andrew and Asri (2021); Wijoyo (2020); Loupatty (2021); 
Evi \& Pramesworo (2021); Bulutoding (2020) shows that tax incentives have a positive and significant effect on taxpayer compliance

H1: Tax incentives have a positive effect on corporate taxpayer compliance

Mastery of tax regulations for taxpayers can improve compliance with tax obligations. Taxpayers try to carry out their obligations in order to avoid the sanctions that apply in tax regulations (Rahayu, 2017). Knowledge and understanding of tax regulations is an understanding and understanding of general provisions and taxation procedures (KUP) which includes how to fill out and submit tax returns (SPT), payments, places of payment, fines, deadlines for payment or reporting of SPT and related regulations. Covid-19 pandemic tax incentives include the Covid-19 tax incentives provided, the criteria that must be met in submitting the Covid-19 tax incentives, the procedure for submitting the Covid-19 tax incentives, how to properly report the realization report, the deadline for reporting the realization report,

If it is related to research, the Theory of Planned of Behavior is relevant to interpret the behavior of taxpayers to be able to fulfill all their tax obligations. According to (Ajzen, 1985), the attitude towards the described behavior can link tax knowledge with taxpayer compliance. This theory explains that this relationship can be built with the presence of internal and external factors. This tax knowledge is included in the internal factors of the taxpayer.Tax knowledge is one of the important elements that can affect taxpayer compliance, especially in supporting accurate determination of tax obligations. Better knowledge and understanding of tax regulations is expected to be able to fulfill tax obligations so as to create a level of taxpayer compliance (Anjanni, Hapsari, \& Asalam, 2019).With good tax knowledge related to tax incentive regulations during the Covid-19 pandemic, taxpayers will be able to obtain their rights in optimally utilizing tax incentives and be able to carry out their tax obligations in accordance with tax regulations, namely depositing taxes that still have to be paid and submitting notification letters and timely realization report.

Empirically Yulianti (2019); Aswati (2018); Rosyida (2018); Bilha (2020); Azam (2021); Purwanto and Astuti (2021); Siregar (2012); Murti (2014) and Anjanni, Hapsari, \& Asalam (2019) prove that tax knowledge has a significant effect on taxpayer compliance. The increasing knowledge of taxation, the behavior of taxpayer compliance is increasing.

H2: Tax knowledge has a positive effect on corporate tax compliance

The existence of a pandemic that makes every country strive to provide the best public services and goods for its citizens should also be a signal of efforts to restore the fiscal contract between the state and society. The reciprocal relationship that has now been shown from the sacrifice of the state should need to be reciprocated by citizens through paying tax compliance. Intention is the basis that will direct a person to comply with tax provisions. Tax intentions can affect the relationship between tax incentives and compliance. If taxpayers have high intentions with their obligations to pay taxes coupled with the Covid-19 pandemic tax incentives provided by the government, it will be able to increase taxpayer compliance.

If it is associated with research, the Theory of planned behavior (TPB) is relevant to interpreting the behavior of taxpayers to be able to fulfill all their tax obligations. The theory of planned behavior (Ajzen, 1991), explains that taxpayer compliance behavior is determined by the taxpayer's intention to comply or not comply with tax provisions. Udayani et al (2017) added that in TPB it is assumed that rational humans will use the available information systematically and then understand the impact of their behavior before deciding to realize this behavior. Intentions (intentions) are determinants and dispositions of behavior, so that individuals have the opportunity and the right time to display the behavior in real terms. namely the individual's beliefs about the existence of things that support or hinder his behavior and his perception of how strongly these things influence his behavior. Control belief forms a perceived behavioral control variable (perceived behavioral control).

Ajzen (1991), Bobek and Hatfield (2003) and Hanno and Violette (1996) state that attitudes toward tax non-compliance have a significant effect on tax non-compliance intentions. In Mustikasari's research (2007) concluded that tax professionals who have a positive attitude towards non-compliance have high tax noncompliance intentions. Tax non-compliance behavior according to Hidayat and Adhi (2010) is based on the intention to not comply with taxes. Ni Made Dwi Ratnadi and I Nyoman Wijana Asmara Putra (2019) examined the competence of intention in moderating the influence of taxation knowledge, moral obligation and services quality to the taxpayer's compliance in cooperative in Bali, Indonesia. The results of the analysis show that the intention is able to moderate the significance of quality tax services on taxpayer compliance. According to Dicriyani and Ketut (2016) examined the effect of service quality and tax knowledge on taxpayer compliance with moderating intentions. The results of this study indicate that the taxpayer's intention strengthens the effect of tax service quality on taxpayer compliance behavior and the effect of tax knowledge on taxpayer compliance behavior. Litawan and Nuratama (2021) conclude that the intention to pay taxes has a positive and significant effect on hotel and restaurant taxpayer compliance in Bangli Regency. The results of this study indicate that the taxpayer's intention strengthens the effect of tax service quality on taxpayer compliance behavior and the effect of tax knowledge on taxpayer compliance behavior. Litawan and Nuratama (2021) conclude that the intention to pay taxes has a positive and significant effect on hotel and restaurant taxpayer compliance in Bangli Regency. The 
results of this study indicate that the taxpayer's intention strengthens the effect of tax service quality on taxpayer compliance behavior and the effect of tax knowledge on taxpayer compliance behavior. Litawan and Nuratama (2021) conclude that the intention to pay taxes has a positive and significant effect on hotel and restaurant taxpayer compliance in Bangli Regency.

\section{H3: Taxpayer intentions strengthen the effect of tax incentives on corporate taxpayer compliance}

The existence of a pandemic that makes every country strive to provide the best public services and goods for its citizens should also be a signal of efforts to restore the fiscal contract between the state and society. The reciprocal relationship that has now been shown from the sacrifice of the state should need to be reciprocated by citizens through paying tax compliance. Intention is the basis that will direct a person to comply with tax provisions. Tax intentions can affect the relationship between knowledge and compliance. If taxpayers have high intentions with their obligations to pay taxes plus have more knowledge in calculating, depositing and reporting taxation, it can improve tax compliance. According to Rahayu (2017) that knowledge of tax regulations is very important to foster obedient behavior. This is because of how someone is obedient if that person does not know how the rules are and how to apply these regulations.

If it is associated with research, the Theory of planned behavior (TPB) is relevant to interpreting the behavior of taxpayers to be able to fulfill all their tax obligations. The theory of planned behavior (Ajzen, 1991), explains that taxpayer compliance behavior is determined by the taxpayer's intention to comply or not comply with tax provisions. Intentions (intentions) are determinants and dispositions of behavior, so that individuals have the opportunity and the right time to display the behavior in real terms. Behavioral intentions are influenced by three components, namely: behavioral beliefs, normative beliefs, and control beliefs. Behavioral belief, namely belief in the outcome of a behavior (outcome belief) and evaluation of the outcome of that behavior. Beliefs and evaluation of these results will form the attitude variable towards the behavior. Normative belief, namely the individual's belief in the normative expectations of others who become his reference, such as family, friends, and tax consultants, and the motivation to achieve these expectations. This normative expectation forms the subjective norm variable for a behavior. The third is control belief, namely the individual's belief about the existence of things that support or hinder his behavior and his perception of how strongly these things affect his behavior. Control belief forms a perceived behavioral control variable (perceived behavioral control). namely the individual's belief in the normative expectations of others who become his reference, such as family, friends, and tax consultants, and the motivation to achieve these expectations. This normative expectation forms the subjective norm variable for a behavior. The third is control belief, namely the individual's belief about the existence of things that support or hinder his behavior and his perception of how strongly these things affect his behavior. Control belief forms a perceived behavioral control variable (perceived behavioral control). namely the individual's belief in the normative expectations of others who become his reference, such as family, friends, and tax consultants, and the motivation to achieve these expectations. This normative expectation forms the subjective norm variable for a behavior. The third is control belief, namely the individual's belief about the existence of things that support or hinder his behavior and his perception of how strongly these things affect his behavior. Control belief forms a perceived behavioral control variable (perceived behavioral control). The third is control belief, namely the individual's belief about the existence of things that support or hinder his behavior and his perception of how strongly these things affect his behavior. Control belief forms a perceived behavioral control variable (perceived behavioral control). The third is control belief, namely the individual's belief about the existence of things that support or hinder his behavior and his perception of how strongly these things affect his behavior. Control belief forms a perceived behavioral control variable (perceived behavioral control).

The results of empirical research have been carried out by researchers, Mustikasari (2007) concluded that tax professionals who have a positive attitude towards non-compliance have high tax non-compliance intentions. In line with Hidayat and Adhi (2010), it is based on the intention to not comply with taxes. The increasing intention of taxpayers, it can strengthen the effect of tax knowledge on taxpayer compliance. Ni Made Dwi Ratnadi and I Nyoman Wijana Asmara Putra (2019) examined the competence of intention in moderating the influence of taxation knowledge, moral obligation and services quality to the taxpayer's compliance in cooperative in Bali, Indonesia. The results of the analysis show that the intention is able to moderate the significance of quality tax services on taxpayer compliance. According to Dicriyani and Ketut (2016) examined the effect of service quality and tax knowledge on taxpayer compliance with moderating intentions. The results of this study indicate that the taxpayer's intention strengthens the effect of tax service quality on taxpayer compliance behavior and the effect of tax knowledge on taxpayer compliance behavior. Litawan and Nuratama (2021) conclude that the intention to pay taxes has a positive and significant effect on hotel and restaurant taxpayer compliance in Bangli Regency.

H4: Taxpayer intentions strengthen the effect of tax knowledge on corporate taxpayer compliance. 


\section{METHODS}

This research was conducted on corporate taxpayers registered at the North Badung Tax Service Office (KPP). The choice of location is because corporate taxpayers who are in the Badung Regency area, especially those registered at the North Badung Tax Office, have a low percentage of corporate taxpayer compliance at the Tax Office, which allows for non-compliance. This can be seen from the ratio of submission of annual corporate tax returns for 2020 which is still low, only reaching $58 \%$ or 2,688 taxpayers out of a total of 4,610 taxpayers. In addition, the Badung district is a tourism area that is highly affected in Bali.

In this study, the population of all corporate taxpayers in the restaurant, hotel, trade, and service sectors registered at the North Badung KPP who are entitled to receive tax incentives during the COVID-19 pandemic in accordance with the provisions amounting to 4,725 taxpayers. Sampling was done by purposive sampling technique. Based on calculations using the Slovin method, from 4.725 taxpayers who are entitled to receive incentives that will be respondents as many as 100 taxpayers. The 100 taxpayers who will be respondents in this study are carried out using a sample collection technique, namely collecting direct data on corporate taxpayers registered at the North Badung Tax Office from the tax consultant office, then sending a google survey form in the form of a questionnaire to taxpayers via whatsapp and email.

\section{RESULTS AND DISCUSSION}

Results of Moderated Regression Analysis (MRA) and Hypothesis Testing

The research hypotheses were tested using Moderated Regression Analysis (MRA). The results of the MRA analysis are presented in Table 1.

Table 1. Results of Moderation Regression Analysis (MRA)

\begin{tabular}{|c|c|c|c|}
\hline Variable & $\begin{array}{l}\text { Unstandardized } \\
\text { coefficients }(\beta)\end{array}$ & t value & $\begin{array}{l}\text { Significant } \\
\text { Value }\end{array}$ \\
\hline Tax Incentives (X1) & 0.181 & 4,836 & 0.000 \\
\hline Tax Knowledge (X2) & 1.242 & 8,830 & 0.000 \\
\hline Taxpayer Intention $(\mathrm{Z})$ & 0.693 & 4,658 & 0.000 \\
\hline Tax Incentives on taxpayer compliance $(\mathrm{X} 1 * \mathrm{Z})$ & 0.003 & 2,232 & 0.028 \\
\hline Tax knowledge on taxpayer compliance $(\mathrm{X} 2 * \mathrm{Z})$ & 0.012 & 4,997 & 0.000 \\
\hline F Uji test & \multirow{2}{*}{\multicolumn{2}{|c|}{81.095}} & Sig $F=0.000$ \\
\hline Adjusted R2 & & & \\
\hline
\end{tabular}

Primary Data, 2021

Based on Table 1, the regression equation can be arranged as follows:

$$
\mathrm{Y}=22.559+0.181 \mathrm{X} 1+1.242 \mathrm{X} 2+0.693 \mathrm{Z}+0.003 \mathrm{X} 1 * \mathrm{Z}+0.012 \mathrm{X} 2 * \mathrm{Z}
$$

\section{Coefficient of Determination}

The results of the analysis show that the value of Adjusted R2 is 0.812 . This means that 81 percent of taxpayer compliance variables can be explained by tax incentive variables, tax knowledge, interaction of tax incentives with taxpayer intentions, interaction of tax knowledge with taxpayer intentions, while the remaining 19 percent is explained by other factors not included in the calculation. model.

\section{Model Feasibility Test Results (F Test)}

The results of the analysis in Table 1 can be seen thatF significance value of 0.000 is less than $=0.05$. It means that the model used in this study is fit (fit).

a) Tax incentives affect taxpayer compliance

b) Tax knowledge has a positive effect on taxpayer compliance.

c) Taxpayer intentions strengthen the effect of tax incentives on taxpayer compliance.

d) The taxpayer's intention weakens the effect of tax knowledge on taxpayer compliance. 


\section{Hypothesis Result}

The effect of Tax incentives on corporate taxpayer compliance

The results of the first hypothesis test presented in Table 1 show that the beta coefficient (b1) is 0.181 with a probability and significance number of $0.000<0.05$; then $\mathrm{H} 1$ is proven to be accepted. This shows that tax incentives have an effect on taxpayer compliance, so the first hypothesis can be accepted.

Based on the attribution theory developed by Heider (1958) is a theory that studies a person's behavior. This theory states that a person's behavior is determined by the relationship between internal and external forces. Based on the attribution theory, the results of this analysis state that tax incentives are external forces that can affect taxpayer compliance. According to (Ajzen, 1985) the attitude towards the described behavior can link tax incentives with taxpayer compliance. This is due to the development and various regulations regarding tax incentives that can indirectly ease the burden on taxpayers, especially for taxpayers affected by COVID-19. With these regulations, taxpayers can take advantage of the facilities provided by the government and increase taxpayer compliance because taxpayers feel helped by the facilities provided.

The results of this analysis are also in line with research conducted by Rachmawati \& Ramayanti (2016); Latif \& Zakaria (2020); Khairiyah \& Akhmadi (2019); Kihanga (2020); Indrayani \& Budiman (2020); Andrew and Asri (2021); Wijoyo (2020); Loupatty (2021); Evi \& Pramesworo (2021); Bulutoding (2020) shows that tax incentives have a positive and significant effect on taxpayer compliance. However, this is not in line with the research of Khairiyah and Akhmadi (2019), Selvi and Ramdhan (2020), Syanti Dewi, Widyasari and Nataherwin (2020, Fochmann \& Kroll (2016); Kastlunger et al. (2011) which explain that tax incentives have no effect on taxpayer compliance

\section{The effect of tax knowledge on corporate taxpayer compliance}

The results of the second hypothesis test presented in Table 1 show that the beta coefficient (b2) is 1.242 with a probability and significance number of $0.000<0.05$, so $\mathrm{H} 2$ is proven to be accepted. This shows that tax knowledge has a positive effect on taxpayer compliance, so the second hypothesis can be accepted. These results mean that the increasing knowledge of taxation owned by taxpayers, the more taxpayer compliance will increase.

Based on the theory Attribution theory developed by Heider (1958) is a theory that studies about a person through internal and external factors. Knowledge of taxation as an external factor that can affect taxpayer compliance. Knowledge and understanding of general provisions and taxation procedures (KUP) that explain the procedures for submitting a Tax Return (SPT), payment, place of payment, fines and deadlines for payment or reporting of SPT can improve taxpayer compliance.

Knowledge of taxation can improve taxpayer compliance, because by knowing the tax regulations used in Indonesia, taxpayers can do tax planning (Tax Planning). Better knowledge and understanding of tax regulations are expected to be able to fulfill tax obligations so as to create a level of taxpayer compliance. In the business world, tax planning is needed as one of the considerations in determining how to business strategy. At the time of planning a business tax knowledge is also very necessary.In addition, with good tax knowledge related to tax incentive regulations during the Covid-19 pandemic, taxpayers can obtain their rights in optimally utilizing tax incentives and can carry out their tax obligations in accordance with tax provisions, namely depositing accrued taxes and deliver notification letters and realization reports on time.

The results of this analysis are in line with research by Razman (2005), Siregar et al. (2012), Adiasa (2013), Handayani et al. (2012) and Murti et al. (2014) proves that tax knowledge has a significant effect on taxpayer compliance. However, this is not in line with researchAjeng Resti Fauzi and Kholida Atiyatul Maula (2020),Darmayasa and Mandia (2019), Nora Hilmia Primasari (2016), Sigit Herdianto (2021), Fita Fitrianingsih, Sudarno, and Taufik Kurrohman (2018), Hardiningsih and Yulianawati (2011), Pranadata (2014), Ratnadi and Putra (2019) and Hardiningsih and Yulianawati (2011) stated that Knowledge or understanding of taxpayers has no effect on taxpayer compliance.

\section{Taxpayer intentions moderate the effect of tax incentives on corporate taxpayer compliance}

The results of the third hypothesis test presented in Table 1 show that the beta coefficient (b4) is 0.003 with a probability and significance number of $0.028<0.05$; then $\mathrm{H} 3$ is proven. It means that there is a moderation of taxpayers' intentions and strengthens the effect of tax incentives on taxpayer compliance, so the third hypothesis can be accepted. These results mean that the higher the intention of the taxpayer, the higher the taxpayer compliance which is supported by the existence of tax incentives.

This result is in line with the theory of planned behavior (TPB), which in this theory states that the direct determinant of individual behavior is the intention to display the behavior. A person's intentions can be predicted through 3 main things, namely his attitude towards it, the subjective norms he has, and the perception of behavioral control (Ajzen, 1991). According to Ajzen (1991), a person's behavior to do or not to do is strongly influenced by intentions. Intention to behave is an indication of a person's readiness to perform the behavior, so that the intention 
to behave is a direct antecedent of the behavior itself. So intention (intention) is a person's tendency to choose to do or not do a job and is assumed to be a motivating factor that exists within the individual that influences behavior.

Thus, the current tax incentives can indirectly increase taxpayer compliance which is influenced by the taxpayer's intention to comply with taxes. This is because taxpayers feel helped by the existence of tax incentive regulations that can ease their tax obligations. Regulations regarding tax incentives require taxpayers to be able to follow the development of related regulations. In this condition, if there is a taxpayer's intention to comply with taxes, the taxpayer will follow the development of tax regulations, especially regarding tax incentives that have changed several times so that taxpayers will understand more about these incentives.

This result is in line with Mustikasari's research (2007) which has proven that among the independent variables of attitude studied, the behavioral control variable that is perceived to have the greatest total influence on the variable of tax professional's intention to behave disobediently. Mustikasari (2007) in his research also states that if the tax professional has a perception that the facilities provided by the company are high or sufficient, the non-compliance with corporate tax is low or vice versa. So with the intention of taxpayers to increase taxpayer compliance with the support of tax incentives provided.

\section{Taxpayer intentions moderate the effect of tax knowledge on corporate taxpayer compliance}

The results of the fourth hypothesis test presented in Table 1 show that the beta coefficient (b5) is 0.012 with a probability and significance number of $0.000<0.05$; then $\mathrm{H} 4$ is proven. It means that there is a moderation of taxpayers' intentions and strengthens the effect of tax knowledge on taxpayer compliance, so the fourth hypothesis can be accepted. The results mean that the increasing intention of taxpayers will increase the relationship of tax knowledge on taxpayer compliance.

This result is in line with the theory of planned behavior (TPB), which in this theory states that the direct determinant of individual behavior is the intention to display the behavior. A person's intentions can be predicted through 3 main things, namely his attitude towards it, the subjective norms he has, and the perception of behavioral control (Ajzen, 1991). According to Ajzen (1991), a person's behavior to do or not to do is strongly influenced by intentions. Intention to behave is an indication of a person's readiness to perform the behavior, so that the intention to behave is a direct antecedent of the behavior itself. So intention (intention) is a person's tendency to choose to do or not do a job and is assumed to be a motivating factor that exists within the individual that influences behavior.

Taxpayers who do not have the intention and know the risks that will be faced will always stick to the decisions they will take, namely the taxpayers will continue to carry out their obligations without paying attention to the risks they already know. The current weakening of economic conditions due to the corona virus pandemic has caused the government to issue various policies to reduce the burden on taxpayers so that there may be gaps for taxpayers to take actions that can reduce the taxpayer's tax burden. In accordance with the results of this study, the current taxpayer's intention is very important to be owned by taxpayers to improve tax compliance.

This result is in line with Mustikasari's (2007) research which has proven that among the independent variables of attitude studied, the behavioral control variable that is perceived to have the greatest total influence on the variable of tax professional's intention to behave disobediently. So that with the intention of the taxpayer, it can strengthen the relationship between tax knowledge and taxpayer compliance.

Taxpayers who have tax knowledge can improve taxpayer compliance, this can be strengthened by the taxpayer's intention so as to increase taxpayer compliance. This is because taxpayers who have the intention to comply by having good knowledge of tax regulations will be able to make taxpayers understand more about taxation, especially for taxpayers who get tax incentives, with good knowledge, taxpayers will find it easier to report their obligations. . With the knowledge of taxation, it indirectly forces taxpayers to be proactive in calculating, paying, and reporting their own taxes.

\section{CONCLUSION}

Tax incentives have an effect on taxpayer compliance. These results accept the first hypothesis which formulates that tax incentives have a positive effect on taxpayer compliance. Tax knowledge has a positive effect on taxpayer compliance. These results accept the second hypothesis which formulates that tax knowledge has a positive effect on taxpayer compliance. Taxpayer intentions strengthen the effect of tax incentives on taxpayer compliance. These results accept the third hypothesis which formulates that taxpayer intention strengthens the effect of tax incentives on taxpayer compliance. The taxpayer's intention strengthens the effect of tax knowledge on taxpayer compliance. These results accept the fourth hypothesis which formulates that taxpayer intentions strengthen the effect of tax knowledge on taxpayer compliance.

The results of the study indicate a tendency to increase tax compliance because taxpayers have good knowledge, especially regarding existing regulations, especially tax incentives that can assist taxpayers in easing their obligations. This finding is expected to be a consideration for the tax office to make tax rules to make it easier for taxpayers to understand.Given the current tax service system has changed to an electronic system so that taxpayers cannot serve directly, so it is very necessary to socialize and understand each rule so that taxpayers can 
easily apply each predetermined rule.

\section{References}

Adelina, D. A., \& Nugrahanto, A. (2021). Pengaruh Pengetahuan Perpajakan Terhadap Kepatuhan Pajak Pada Self Assessment System di Indonesia. Jurnal Informasi, Perpajakan, Akuntansi, Dan Keuangan Publik, 16(1), 133-156.

Adiasa, Nirawan. (2013). Pengaruh Pemahaman Peraturan Pajak Terhadap Kepatuhan Wajib Pajak Dengan Moderating Preferensi. Accounting Analysis Journal. Jurusan Akuntansi, Fakultas Ekonomi. Universitas Negeri Semarang: Semarang.

Ajzen, Icek. (1991). The Theory of Planned Behavior. Organizational Behavior and Human Decision Process". Vol: 50. pp 179-211.

Ajzen, Icek., Fishbein, Martin. (1969). The Prediction of Behavioral Intentions in a Choice Situation. Journal of Experimental Social Psychology. Vol: 5. pp $400-416$.

Alfina, Z., \& Diana, N. (2021). Pengaruh Insentif Perpajakan Akibat Covid-19, Pemahaman Perpajakan, Kesadaran Wajib Pajak Terhadap Kepatuhan Wajib Pajak Dalam Menyampaikan Surat Pemberitahuan Tahunan (Studi Pada Wajib Pajak Yang Terdaftar Di Kpp Pratama Malang Utara). Jurnal Ilmiah Riset Akuntansi, 10(04).

Anggraeni, W. A., Dahlan, M., \& Yudianto, I. (2021). Determinan Intensi Kepatuhan Wajib Pajak Pelaku Bisnis Online Berdasarkan Theory of Planned Behavior. Syntax Literate; Jurnal Ilmiah Indonesia, 6(4), 2083-2092.

Anjanni, I. L. P., Hapsari, D. W., \& Asalam, A. G. (2019). Pengaruh penerapan self assessment system, pengetahuan wajib pajak, dan kualitas pelayanan terhadap kepatuhan wajib pajak (Studi pada Wajib Pajak Orang Pribadi Non Karyawan di KPP Pratama Ciamis Tahun 2017). Jurnal Akademi Akuntansi, 2(1).

Aswati, W. O., \& Mas'ud, A. dan Tuti Nurdianti Nudi. (2018). Pengaruh Kesadaran Wajib Pajak, Pengetahuan Pajak, Dan Akuntabilitas Pelayanan Publik Terhadap Kepatuhan Wajib Pajak Kendaraan Bemotor (Studi Kasus Kantor UPTB Samsat Kabupaten Muna). Jurnal Akuntansi dan Keuangan, 3, 1.

Benk, S. Çakmak A. F. \& Budak, T. (2011). An investigation of tax compliance intention: A theory of planned behavior approach. European Journal of Economics. Finance and Administrative Sciences. Vol: 28. pp 181-188

Bobek, Donna D. Richard C. Hatfield. (2003). An Investigation of the Theory of Planned Behavior and The Role of Moral Obligation in Tax Compliance. Behavioral Research in Accounting. Vol. 15

Budiman, N. A., Indaryani, M., \& Mulyani, S. (2020). Dampak Covid-19 dan Pemanfaatan Insentif Pajak terhadap Keberlangsungan Usaha pada UMKM Tenun Troso Jepara. Jurnal Manajemen dan Keuangan, 9(3), 276-285.

Bulutoding, L., Abd Hamid, H., Suwandi, S., Memen, M., Sari, S., \& Rahmah, N. (2020). The Impact of Covid19 Pandemic on Taxation in Indonesia. International Journal of Recent Scientific Research, 11(06), 38775-38782.

Das-Gupta, Arindam. Ghosh. Shanto. Mookherjee. Dilip. (2004). Tax Administration Reform and Taxpayer Compliance in India. International Tax and Public Finance. ABI/INFORM Research. Vol: 11. pp 575

Dicriyani, N. L. G. M., \& Ketut, B. I. (2016). Pengaruh Kualitas Pelayanan dan Pengetahuan Perpajakan Pada Perilaku Kepatuhan Wajib Pajak Dengan Niat Sebagai Pemoderasi. E-Jurnal Ekonomi Dan Bisnis Universitas Udayana, 10, 3329-3358.

Erwin, Harinurdin. (2009). Perilaku Kepatuhan Wajib Pajak Badan. Jurnal Ilmu Administrasi dan Organisasi. Volume 16, Nomor 2: 96-104. ISSN 0854-3844

Faizal, S. M., Zaini, R. M., \& Somasundaram, N. R. (2021). Tax Awareness and Tax Knowledge of Students at Secondary School Level in Malaysia. International Business Education Journal, 14(1), 65-70.

Francis, Jillian J. Martin P Eccles. Marie Johnston. Anne Walker. Jeremy Grimshaw. Robbie Foy. Eileen F S Kaner. Liz Smith. Debbie Bonetti. (2004). Constructing Questionnaires Based on The Theory of Planned Behavior: A Manual for Health Services Researchers. Centre for Health Services Research. University of Newcastle. United Kingdom. 
Feld, Lars P. Bruno S. Frey. (2002). Trust Breeds Trust: How Taxpayers are Treated. Economics of Governance. Vol: 3. pp 87-99.

Fischer, Carol M., Wartick, Martha., Mark, Melvin M. (1992). Detection Probability and Tax-payer Compliance: A Review of Literature. Journal of Accounting Literature. Vol. 11

Handayani, Sapti. Wuri., Faturokhman, Agus., Pratiwi, Umi. (2011). Faktor-Faktor yang Mempengaruhi Kemauan Membayar Pajak Wajib Pajak Orang Pribadi yang Melakukan Pekerjaan Bebas. E-Jurnal Universitas Jenderal Soedirman.

Hardika, N. Sentosa. (2006). Pengaruh Lingkungan dan Moral Wajib Pajak Terhadap Sikap dan Kepatuhan Wajib Pajak Pada Hotel Berbintang Di Provinsi Bali. Disertasi. Universitas Airlangga: Surabaya.

Hardiningsih, Pancawati., Yulianawati, Nila. (2011). Faktor-faktor yang mempengaruhi kemauan membayar pajak. Dinamika Keuangan dan Perbankan. Vol: 3. No. 1 ISSN :1979-4878. pp $126-142$

Hendrawati, E., Pramudianti, M., \& Abidin, K. (2021). Pengetahuan Pajak, Sanksi Pajak, Modernisasi Sistem, Kondisi Keuangan Terhadap Kepatuhan Wajib Pajak Umkm Selama Pandemi Covid-19. Fair Value: Jurnal Ilmiah Akuntansi dan Keuangan, 4(1), 214-230.

Hidayat, Widi., Nugroho, Argo. Adhi. (2010). Studi Empiris Theory of Planned Behavior dan Pengaruh Kewajiban Moral pada Perilaku Ketidakpatuhan Pajak Wajib Pajak Orang Pribadi. Jurnal Akuntansi dan Keuangan. Vol: 8412. No 2. Universitas Airlangga: Surabaya

Hoy, W.K. dan Tarter, C.J. (2004). Organizational justice in schools: no justice without trust. International Journal of Educational Management. Vol:18. Nomor 4. pp 250-259

Jibreel, El-Maude Gambo1. Mas'ud. Abdulasalam. Nasidi. Mustapha. Simon. Oginni Oyewole. 2014. Tax Complexity and Tax Compliance in African Self-Assessment Environment. International Journal of Management Research \& Review. Volume 4 Issue 5 Article No-4/575-582. ISSN: 2249-7196

Kastlunger, B., Muehlbacher, S., Kirchler, E., \& Mittone, L. (2011). What goes around comes around? Experimental evidence of the effect of rewards on tax compliance. Public Finance Review, 39(1), 150-167.

Kim, E., dan Tadisina, S., (2003). Customer's Initial Trust in E-Business: How to Measure Customer's Initial Trust. Proceedings of Ninth Americas Conference on Information Systems. pp. 35-41

Koeszegi, S.T. (2004). Trust-building strategies in inter-organizational negotiations. Journal of Managerial Psychology. Vol:19. No.6. pp 640-660

Latief, S., Zakaria, J., \& Mapparenta, M. (2020). Pengaruh Kepercayaan Kepada Pemerintah, Kebijakan Insentif Pajak dan Manfaat Pajak Terhadap Kepatuhan Wajib Pajak. CESJ: Center of Economic Students Journal, 3(3), $270-289$

Litawan, I. K., \& Nuratama, I. P. (2021). Pengaruh Modernisasi Sistem Administrasi Perpajakan, Niat Membayar Pajak, Dan Lingkungan Wajib Pajak Terhadap Kepatuhan Wajib Pajak Hotel Dan Restoran. Hita Akuntansi dan Keuangan, 2(3), 252-265.

Loupatty, L. G. (2021). Effectiveness Of Tax Incentive Implementation for Taxpayer Impact of The Corona Virus Desease Pandemic 2019 Based On PMK-110/PMK. 03/2020 In Ambon City. International Journal of Multi Science, 2(03), 24-49.

Masruroh, Siti, Zulaikha. (2013). Pengaruh Kemanfaatan NPWP, Pemahaman Wajib Pajak, Kualitas Pelayanan, Sanksi Perpajakan terhadap Kepatuhan Wajib Pajak (Studi Empiris pada WP OP di Kabupaten Tegal). Diponegoro Journal of Accounting. Vol: 2. Nomor 4. Tahun 2013

Mandowally, B. M., Allolayuk, T., \& Matani, C. D. (2020). Pengaruh Sanksi Perpajakan, Pelayanan Fiskus dan Pengetahuan Perpajakan terhadap Kepatuhan Wajib Pajak Orang Pribadi (Studi Empiris Pada Wajib Pajak Orang Pribadi yang Terdaftar di KPP Pratama Jayapura). Jurnal Akuntansi Dan Keuangan Daerah, 15(1), 46-56.

Meita, Rachmawati Oktaviani. (2015). Determinan Kepatuhan Wajib Pajak Badan dengan Niat Sebagai Pemediasi 
Dari Perspektif Planned Behaviour Theory. Jurnal Bisnis dan Ekonomi (JBE). Vol: 22. No. 185. pp 85-95

Muarifah, Tanzilah. (2013). Pengaruh Pengetahuan Pajak, Kualitas Petugas Pajak dan Sikap Wajib Pajak Terhadap Kepatuhan Wajib Pajak (Studi kasus pada Wajib Pajak Orang Pribadi yang terdapat pada KPP Pratama Semarang Selatan). Jurusan Akuntansi Fakultas Ekonomi dan Bisnis. Universitas Dian Nuswantoro

Murti, Hangga. Wicaksono., Sondakh, Jullie. J., Sabijono, Harijanto. (2014). Pelayanan Fiskus dan Pengetahuan Perpajakan terhadap Kepatuhan Wajib Pajak Orang Pribadi di Kota Manado. Jurnal EMBA. Vol:.2 No.3. pp 389398.

Nazzira Rasya Fazriputri, Ni Putu Eka Widiastuti, (2021). Pengaruh Sosialisasi Dan Pemahaman Insentif Pajak Terhadap Kepatuhan Wajib Pajak Pada Masa Pandemi Covid-19 (Studi Pada Pemilik UMKM di Kota Bekasi)

Nurkhin, A., Novanty, I., Muhsin, M., \& Sumiadji, S. (2018). The influence of tax understanding, tax awareness and tax amnesty toward taxpayer compliance. Jurnal Keuangan Dan Perbankan, 22(2), 240-255.

Putri, K. J., \& Setiawan, P. E. (2017). Pengaruh Kesadaran, Pengetahuan Dan Pemahaman Perpajakan, Kualitas Pelayanan Dan Sanksi Perpajakan Terhadap Kepatuhan Wajib Pajak. E-Jurnal Akuntansi Universitas Udayana, 18(2), 1112-1140.

Purwanto, W., Harimurti, F., \& Astuti, D. S. P. (2016). Pengaruh tingkat ekonomi, pengetahuan pajak dan kepercayaan masyarakat terhadap kepatuhan pajak bumi dan bangunan dengan kontrol petugas desa sebagai variabel moderating. Jurnal Akuntansi Dan Sistem Teknologi Informasi, 11.

Parasuraman, A., Zeitham, A. Berry, L. (1988). Servqual: A Multiple - Item Scale for Measuring Consumer Perception of Service Quality. Journal of Retailing. 64 (1). http://areas.kenan-flagler.unc.edu.

Pranadat, I Gede Putu. (2014). Pengaruh Pemahaman Wajib Pajak, Kualitas Pelayanan Perpajakan, dan Pelaksanaan Sanksi Pajak Terhadap Kepatuhan Wajib Pajak Orang Pribadi Pada Kantor Pelayanan Pajak Pratama Batu. Jurnal Mahasiswa FEB. Vol: 2. No. 2

Rachmawati, N. A., \& Ramayanti, R. (2016). Manfaat Pemberian Insentif Pajak Penghasilan dalam Kepatuhan Wajib Pajak UMKM. Jurnal Akuntansi, Ekonomi dan Manajemen Bisnis, 4(2), 176-185.

Ratnadi, N. M. D., \& Putra, I. N. W. A. (2019). The Competence of Intention in Moderating the Influence of Taxation Knowledge, Moral Obligation and Service Quality to Taxpayer's Compliance in Cooperative in Bali, Indonesia.

Rizal, Mohd Palil. Fariq. Ahmad Mustapha. (2011). The Evolution and Concept of Tax Compliance in Asia and Europe. Australian Journal of Basic and Applied Sciences. Vol: 5(11). pp 557-563

Saputro, R., \& Meivira, F. (2020). Pengaruh tingkat pendidikan pemilik, praktik akuntansi dan persepsi atas insentif pajak terhadap kepatuhan pajak UMKM. Jurnal EMBA: Jurnal Riset Ekonomi, Manajemen, Bisnis dan Akuntansi, 8(4).

Sari, M. M. R., \& Afriyanti, N. N. (2012). Pengaruh Kepatuhan Wajib Pajak dan Pemeriksaan Pajak terhadap Penerimaan PPh Pasal 25/29 Wajib Pajak Badan pada KPP Pratama Denpasar Timur. Jurnal Ilmiah Akuntansi dan Bisnis, 7(2), 1-21.

Septyana, K. P., \& Suprasto, H. B. (2019). Effect of taxation knowledge, Fiscus service, and tax sanctions on tax obligation compliance with tax amnesty as moderated variables. International Research Journal of Management, IT and Social Sciences, 6(6), 111-117.

Siregar, Yuli. Anita., Saryadi., Listyorini, Sari. (2012). Pengaruh pelayanan fiskus dan pengetahuan perpajakan terhadap kepatuhan wajib pajak (Studi Empiris terhadap Wajib Pajak di Semarang Tengah). Jurnal Ilmu Administrasi Bisnis. Jurusan Administrasi Bisnis Fakultas Ilmu Sosial dan Ilmu Politik Universitas Diponegoro.

Syahril, Farid. (2013). Pengaruh Tingkat Pemahaman Wajib Pajak dan Kualitas Pelayanan Fiskus Terhadap Tingkat Kepatuhan Wajib Pajak PPh Orang Pribadi (Studi Empiris Pada KPP Pratama Kota Solok). E-Jurnal Universitas Negeri Padang 
T. Asmarany, T. E. Putri, and Icih. (2020). Pengaruh Kesadaran Wajib Pajak, Kualitas Pelayanan Fiskus, dan Sosialiasi Perpajakan Terhadap Kepatuhan Wajib Pajak PP 23 Tahun 2018 Tentang Wajib Pajak Yang Memiliki Peredaran Tertentu dengan Persepsi Keadilan Wajib Pajak Sebagai Variabel Pemoderasi. JRAK, vol. 11, No. 83

Udayani, A. A. K. F., \& Sari, M. M. R. (2017). Pengaruh pengendalian internal dan moralitas individu pada kecenderungan kecurangan akuntansi. E-Jurnal Akuntansi Universitas Udayana, 18(3), 1744-1799.

Wibawa, I. P. A. S., Jati, I. K., Sari, M. M. R., \& GdeAry, I. (2021). The Influence of Tax Understanding, Technology Readiness, Ease of Using e-Filing on MSME Individual Taxpayers Compliance.

Wijoyo, H., Akbar, M. F., Safii, A. R., Prasada, D., Yusuf, A., Sudarsono, A., \& Widiyant, W. (2021). The Effect of Tax Stimulus during the Covid-19 Pandemic in Improving the Performance of Taxpayers. Available at SSRN 3873695 .

Woro, Theresia. Damayanti., Suparnomo. (2013). Apa kata mereka? Pengetahuan, Sikap Dan Niat Untuk Patuh Calon Pelaku Pajak. Akuntabilitas Jurnal Ilmiah Akuntansi. ISSN: 1412-0240. Vol: 12 (1)

Yulianti, A., \& Kurniawan, A. (2019). Pengaruh Pengetahuan Perpajakan Dan Persepsi Keadilan Terhadap Tingkat Kepatuhan Wajib Pajak Melalui Kepercayaan. Jurnal Riset Keuangan Dan Akuntansi, 5(1).

Zulaikha, Nugroho R.A. (2012). Faktor-Faktor yang Mempengaruhi Kemauan Untuk Membayar Pajak Dengan Kesadaran Membayar Pajak Sebagai Variabel Intervening (Studi Kasus Wajib Pajak Orang Pribadi Yang Melakukan Pekerjaan Bebas Yang Terdaftar Di KPP Pratama Semarang Tengah Satu. Diponegoro Journal of Accounting. ISSN: 2337-3806. Vol: 1 (2) 